\title{
RICHARD MESSER, „PŘICESTOVALÁ OSOBNOST““. K JEDNÉ HABILITAČNÍ ZÁPLETCE
}

\author{
MICHAL TOPOR
}

\section{RICHARD MESSER, OUTSIDER: ON THE VICISSITUDES OF ONE HABILITATION PROCESS}

In 1923, Richard (Meszleny-)Messer, a Germanist who lived in Bratislava, tried to habilitate at the Czech Faculty of Philosophy of the Charles University on the basis of a Czech-written study on R. M. Rilke and a lecture on epic Mariology in German poetry from the Middle Ages until the present. Despite the support of many colleagues (especially A. Novák, A. Kraus, and O. Fischer), the habilitation process was after several months stopped. This contribution presents an outline of the main factors and stages of this ultimately failed process, as far as one can discern them from textual evidence, with the aim of uncovering the background of the events.

Keywords: Faculty of Philosophy of the Charles University - German studies - habilitation - Richard Messer

DOI: $10.14712 / 23365730.2019 .16$

„[...] jestli pan Messer bude potvrzen, nebo ne - to mně je úplně lhostejné. Tobě snad ne, uznávám, ale préec, zaplni-li to půl stránky Tvého stručného dopisu - nic mi to nepovídá, nebo snad až př́lišs mnoho $[\ldots]^{\text {“. }}{ }^{1}$

„U nás není nic nového. Jen lift nejezdí a večer se už v ústředním topení netopí. A náš redaktor Laufer má dceru. Prof. Křepinský ještě neumřel. A zase brzy něco pošlete.“2

\section{Max Křepinský zasahuje}

Následující skica bilancuje a inscenuje textové stopy krachu jednoho habilitačního pokusu. Nejde však přitom jen o sondu biograficko-př́ípadovou: re/konstruovaná individuální kauza umožňuje rozehrát určité aspekty obecnějšího dobového dosahu.

V půli června 1922 požádal Richard Meszleny-Messer ${ }^{3}$,slavný profesorský sbor fakulty filozofické Karlovy univerzity“, „aby byl pověren úkolem lektora pro německý jazyk“

1 Literární archiv Památníku národního písemnictví (dále LA PNP), fond Otokar Fischer, korespondence přijatá, Blažena Fischerová Otokaru Fischerovi, 28. 10. 1923.

2 LA PNP, fond Arne Laurin, A. Laurin Vincenci Lesnému, 10. 4. 1928.

3 Narodil se roku 1881 v Pančevu jako Richard Messer do německé židovské rodiny právníka Filipa Messera; maturoval v Novim Sadu. Od podzimu 1903 studoval filologii na univerzitě v Budapešti (někdy v té době si osvojil jméno Meszleny), semestr 1905/1906 strávil v Grenoblu, jaro/léto 1906 v Heidelbergu. Budapešt'ská studia zakončil v roce 1908 mad’arskojazyčnou prací věnovanou poezii Heinricha Wilhelma von Gerstenberg. 
na pražské české univerzitě. ${ }^{4} \mathrm{~V}$ krátkém dobrozdání, jež k žádosti připojili germanisté Arnošt Kraus a Josef Janko, byl uchazeč traktován jako „chvalně známý literární historik“, který je pro úkol lektora výborně kvalifikován, v podobném směru se nesl také Messerův životopis, který pro návrh na ustanovení sepsal A. Kraus. Takto vybavené žádosti adresované nakonec ministerstvu školství a národní osvěty bylo vyhověno: počínaje podzimem 1922 se Meszleny-Messer ujal vedle Otokara Fischera na pražské české filozofické fakultě „řizení jazykového kurzu německého pro začátečníky“.5

Počátkem března 1923 Messer (mad'arské části jména se mezitím vzdal) inicioval řízení, v jehož rámci se ucházel o docenturu na pražské české filozofické fakultě. ${ }^{6}$ Několik týdnů nato se poprvé představil jako českojazyčný autor; ${ }^{7}$ výsledné znění monografie Moderni pražský mystik Rainer Maria Rilke přitom lze sotva připsat jen jemu - sám na to ostatně upozornil úvodním poděkováním Růženě Vackové a Renému Wellkovi, kteří „pomáhali při jazykové úpravě této knihy". ${ }^{8}$ Pasáž o Rilkovi se Messer chystal vetknout i do kandidátské přednášky, již vymezil tématem „epické mariologie německého básnictví od středověku až do přitomné doby". ${ }^{9}$ Průběh habilitačního řízení byl nicméně v polovině května ${ }^{10}$

V letech 1909-1910 žil v Bernu, v roce 1912 se usadil v Ženevě, obhájil tu habilitační práci (Wilhelm Meister theatralische Sendung) a vyučoval na zdejší univerzitě. Do Budapešti se vrátil se začátkem války. V předválečných i válečných časopisecky publikovaných statích se zabýval především aspekty a proměnami velkých epických žánrů, pohybuje se v rozmezí jdoucím od Schillera či Goetha ke Carlu Spittelerovi: teprve na konci roku 1918 se dočkala vydání Meszlenyho studie Karl Spitteler und das neudeutsche Epos. Během války se usadil v Poszony (pozdější Bratislavě), vyučoval na zdejší obchodní akademii, po válce byl tajemníkem místního Uměleckého spolku (Kunstverein), v roce 1920 řídil časopis Das Riff, v němž vedle prací německých a mad’arských literátů otiskoval také Pickovy překlady z české literatury. Po zániku listu byl zaměstnán v bance, zanedlouho našel místo v profesorském sboru mad'arskojazyčné pobočky Československé státní obchodní akademie, v průběhu roku 1921 se však domohl delší dovolené, pobýval v Praze a snažil se zlepšit svou češtinu - v této době se utvářel Messerův přátelský vztah s Otokarem Fischerem (srov. dopisy R. Messera Fischerovi, LA PNP, f. O. Fischer) a vznikl patrně nejen plán lektorského angažmá na pražské české filozofické fakultě, nýbrž i projekt habilitační (srov. zde dále citovaný dopis A. Novákovi z 22. 5. 1923).

4 Archiv Univerzity Karlovy (dále AUK), fond Filozofická fakulta UK 1882-1966 (1970) /dále f. FF UK/, kart. 41, i. č. 484, Richard Messer, Návrh na ustanovení dra R. Meszleny-Messera lektorem jazyka německého, 14. 6. 1922.

5 AUK, f. FF UK, kart. 41, i. č. 484, R. Messer, Návrh, aby jazykový kurs německý pro začátečníky převzal lektor Dr. Meszleny (opis), 20. 10. 1922, podepsáni Josef Janko a Arnošt Kraus. Meszleny-Messer vedl v zimním semestru 1922/1923 dva kurzy, jeden v semináři ve Veleslavínově ulici, jeden na právnické fakultě, a O. Fischer si ponechal jeden konverzační kurz pro pokročilé. Toto obsazení bylo patrně poněkud překotné v Seznamu přednášek pro zimní běh 1922/23 ještě Meszleny-Messer nefiguroval.

6 Srov.: ,[...] v těchto dnech zadal jsem svoji habilitační žádost v úplném srozumění s pp. prof. Janko, Krausem a Fischerem a přeju si, aby její cesta byla co nejšt'astnější. Nechtěl jsem zneužiti [sic] Vaší laskavé [sic] nabídnuté pomoci, totiž prohlídky mé habilitační práce v rukopise, dovolím si však poslati Vám první kartáčovný otisk, jejž, doufám, budu míti v 8-10 dnech. Samozřejme [sic] velmi bych Vám byl povděčen za důkladnou prohlídku [...]“ (LA PNP, f. A. Novák, dopis Richarda Meszleny-Messera Arne Novákovi, Praha, Královské Vinohrady, 2. 3. 1923).

7 Srov.: „[...] zasílám Vám výtisk své, právě vyšlé knihy. Milerád byl bych v ni [sic] vyjádřil veřejně svou vděčnost' [sic] tak pro laskavé prohlédnutí kartáčových otisků jak [sic] vůbec pro všestrannou podporu, které se již teším [sic] několik let.“ (LA PNP, f. A. Novák, dopis Richarda Messera Arne Novákovi, Praha, Královské Vinohrady, 26. 4. 1923).

8 Richard Messer, Moderní pražský mystik Rainer Maria Rilke, Praha, Bedřich Kočí 1923, s. [III].

9 AUK, f. FF UK, kart. 3, i. č. 42, Protokol o schůzi profesorského sboru filosofické fakulty Karlovy university konané ve čtvrtek dne 26. dubna 1923; srov. Richard MESSER, Epická mariologie německého básnictví v středním a novém věku, Časopis pro moderní filologii a literatury 10, 1923/1924, č. 2, březen 1924, s. 122-132, č. 3/4, červen 1924, s. 224-232.

10 Do začátku května 1923 germanista Jan Ferdinand Ježek, toho času jako soukromý docent přednášející na české filozofické fakultě (v ZS 1921/1922 na téma „studie a podobizny z doby poetického realismu“, v LS 
na jedné ze schůzí fakultního profesorského sboru zkomplikován námitkami formulovanými romanistou Maxem Křepinským. ${ }^{11}$ Messer o tom několik dní nato informoval Arneho Nováka: „Zdejši fakulta se již dř́ve usnesla habilitovati mne dne 17. t. m. bez kolokvia jen na podkladě jednoduché přednášky. Tento návrh byl bez námitek príjat. Nato byla proti mně vyvolána neslýchaná kampan̆. Profesor Křepinský dosáhl zrušení rozhodnutí a má věc byla nyní prìkázána rozmnožené komisi, v niž mimo dosavadních pánů prof. Krause, Janka a Fischera zasedaji také pp. Zubatý, Křepinský a Šusta. Ta má nyní navrhnouti, má-li býti o mé věci jednáno dále v zimním semestru, či zda má býti už nyní zastavena. Obžaloba prof. Křepinského nepřinesla proti mně při ,nejlepši " vůli nic jiného než doklady z knihy o Spittelerovi, z niž má býti žrejmo, že jsem přespř́liš , deutsch', než abych mohl býti připuštěn na československou univerzitu.

Věc se má nyní takto: tři páni z původní komise mi zůstanou nakloněni; p. prof. Šusta je, jak známo, př́stupen intervenci prof. Heidlera; na prof. Křepinského vi̊bec nemyslím, ten je - bưh ví, proč vlastně - mým zaprisáhlým neprítelem; zbývá tudiž nade vše dưležitý hlas prof. Zubatého, a tu si dovoluji otázku, zda byste mohl př́mo či nepř́mo zastupovati mou věc u prof. Zubatého? Kdybyste tak učinil, zvitězil bych jistotně v těžké věci, za niž jsem šel věren svým směrnicím a již po půldruhého roku obětuji a dávám vše, co je v mé moci. [...]

Dovolte mi, milý pane profesore, abych pomijeje úplně vlastni těžký osud řekl Vám jen tolik: Kdybych já jakožto vydavatel ,Riffu ' [vycházel v Bratislavě od února do záŕí 1920, M. T.], jakožto sledovatel zásady, že i Němec nebo Mad'ar může a musí býti dobrým československým republikánem, a že to neni nijakou zradou na jeho vlastni národnosti, naopak, kdybych já právě v této věci měl utrpěti zahanbujici ponižení, ukazovalo by se na mne po celém Slovensku prstem a řeklo by se: tak se stane každému z menšiny, kdo se připoji k československému státnímu pojetí [...]“..12

Přetavit Messerovo „bůh ví, proč“, směřující do osobní roviny, v nějakou určitější dešifraci důvodů, není snadné, stejně jako nelze - pokud vím - disponovat žádným podrobným

1922 a ZS 1922/1923 o německé literatuře „v období realismu naturalistického“, v LS 1923 měl přednášet na téma „aktivism“/srov. Seznamy přednášek, které se budou konati na Universitě Karlově v Praze..., podle let a semestrů/, avšak koncem února čtení odvolal), datoval předmluvu ke své knize Bratři a demokraté. Několik studii o německé literatuře s hlediska humanity a demokracie (Praha, vl. n.). Vzhledem k pozdějším okolnostem stojí za zmínku, že tu Ježek - patrně v souvislosti s několika řádky, jež sám věnoval Rilkovu zjevu - v soupise literatury uvedl i Messerovu českou monografii (s. 158; tak i ve 2. vyd. práce - nadepsané tentokrát $M y$ a Němci. Německá otázka ve světle německé literatury, Praha, vl. n. 1923, předmluva z prosince t. r.).

11 „Návrh prof. Křepinského, aby bylo revotováno usnesení profesorského sboru z 26. dubna 1923 ve věci habilitace Dra R. Messera přijat jednomyslně. Prozkoumání ostatních návrhů, které učinil prof. Křepinský stran téže habilitace, svěřeno dosavadní habilitační komisi, rozšířené o profesory Křepinského, Šustu a Zubatého." (AUK, f. FF UK, kart. 3, i. č. 42, Protokol o schůzi... konané 17. května 1923). - Max Křepinský (nar. 1875 v Turnově) se na pražské české filozofické fakultě habilitoval již v roce 1908 - „pro obor jazyka a literatury francouzské se zvláštním zřetelem k době staré" (AUK, f. FF UK, kart. 35, i. č. 424, Maxmilián Křepinský, spisy související s odchodem Jana Urbana Jarníka z funkce a jmenováním Křepinského provizorním vedoucím romanistického semináře FF UK, 17. 1. 1908 a 22. 10. 1908); v záŕí 1919 byl jmenován řádným profesorem (tamtéž, žádost M. Křepinského o poskytnutí výhod, 13. 11. 1922). V souvislosti s Křepinského vystoupením proti Messerovi nabude př́značného osvětlení hold, jímž se ke Křepinskému obrátil v ř́ijnu 1945 orientalista a toho času děkan filozofické fakulty Jan Rypka: „Vždy jsem si Vás hluboce vážil. Připoutalo mne Vaše vřelé vlastenecké cítění a Vaše nezištnost. [...] Svou prřímočarost a ryzost jste osvědčil nesčíslněkrát, vždy mužně vystoupiv všude, kde jste nesouhlasil, varuje s moudrým rozhledem sbor profesorský před důsledky.“ (AUK, f. FF UK, kart. 35, i. č. 424, dopis J. Rypky M. Křepinskému, 8. 10. 1945).

12 LA PNP, f. A. Novák, dopis Richarda Messera Arne Novákovi, Praha, 22. 5. 1923. 
záznamem Křepinského květnového vystoupení ani jeho dalších (třebas i soukromých) vyjádření v tom směru. Křepinský se tak v kauze vznáší jako klíčový, avšak obtižně uchopitelný aktér.

\section{Šetření}

V dopise Novákovi Messer konstatoval, že Křepinský poukázal k jeho spittelerovským pracím dovršeným v knize Karl Spitteler und das neudeutsche Epos a vyvodil z nich tezi o nekompatibilitě jeho němectví s rámcem či ideálem „,̌eskoslovenské univerzity“. V další rekonstrukci Křepinského argumentace lze postoupit prostřednictvím komentářů, jimiž se $\mathrm{k}$ ní nedlouho poté - patrně s výhledem $\mathrm{k}$ další, letní schůzi profesorského sboru - vyslovili Arnošt Kraus a Otokar Fischer, do značné míry překrývavě, téměř totožně (kooperace je zjevná). ${ }^{13}$ Výhrady, jimiž Křepinský podepřel návrh o revotaci Messerova habilitačního řízení, Kraus shrnul do čtyř tezí:

„1. Dr Messer je Němec a Němec nemůže býti učitelem na české univerzitě;

2. Dr Messer neumí česky a není príípustno, aby na české univerzitě přednášel jiným jazykem než československým;

3. Dr Messer je smýšlení protistátního;

4. Dr Messer svou povahou nehodí se na učitele univerzitního [...].“

V rozkladu k jednotlivým bodům Kraus vyznačil trojici spittelerovských pasáží, jež tedy Křepinský pravděpodobně předložil jako doklady pro třetí z tezí, a sice: 1) Messerovu „teorii, že epos žádá pohybu mas pod oligarchickými vi̊dci“, a rozeznání „takového pohybu, obdobného tažení Achaiu nebo Nibelungů, ve velké mobilizaci německé“; 2) snahu „,omluvit [Spittelera] před německými čtenáŕi poukazem na vlivy, pod kterými psal mladý básník, tj. na protiněmeckou tendenci švýcarských novin“; 3) to, že Messer v předmluvě ke knize Karl Spitteler und das neudeutsche Epos jen krátce odbyl Spittelerovu válečnou protipruskou kontroverzi. Messerovu morální labilitu Křepinský ilustroval - dle slov Krausových jednak lehkostí, s níž se „vzdává jména v literatuře známého“, jednak srovnáním: vždyt' vojenské úřady zamítly Messerovu žádost, aby „byl převzat jako di̊stojník do čs. vojska [...]“. ${ }^{14}$ Způsob, jímž se Kraus posléze vyrovná s Křepinského tezemi (aby tuto operaci nechal vyústit v konstatování: „Př́čin věcných proti němu není a politické úvahy, maji-li míti misto, mluví pro něho"), lze sledovat v první z príloh (Apendix), faktem květnových dní byla náhlá trhlina v cestě, již Messer podáním habilitační žádosti nastoupil.

Fischer se ve svém expozé - v pasáži o „kandidátově způsobilosti vědecké“ - dotkl mj. rozporného príjetí jeho starších prací a podezřelého mlčení německé odborné obce nad výkonem skutečně stěžejním, totiž monografií o Spittelerovi. Co se týče „knihy o Rilkovi“, připustil, že „,k úplnému zvládnuti těchto otázek byla by záhodna důvěrnějši znalost českého prostředi", přesto monografii představil jako chvályhodný projev, odpovídající ostatně ideji „vykládání německé literatury v Čechách [...] ve spojitosti se slavistickými problémy“, respektive ,požadavku, který právě v poslední době byl z české strany formulován, nap̌r.

13 LA PNP, f. O. Fischer, cizí rukopisy, fasc. Messer - Křepinský. Doklady k univerzitní záležitosti, Vyjádření prof. Arnošta Krause a Otokara Fischera, květen 1923.

14 Tamtéž. 
p. prof. F. X. Šaldou, o nutnosti celkového pohledu na německou literaturu u nás a její jakési československé podbarveni". V dalším odstavci Fischer zdůraznil Messerův ,,volný a bystrý rozhled, jeho erudici i školenost a podnětůplnou schopnost kombinačni", ačli doprovázené „sklony a manýry [...] k duchaplnickému esejismu a vágnímu stanovování vztahů mezi uméleckými jevy“. Vyzdvihl kandidátův „smysl pro detail“, byt' se ,uplatňuje na úkor celkové kompozice dila“, zmínil ,jeho náchylnost k nadsázkám a [...] přiliš odvážné kombinace na poli látkoslovném“ - „kteréžto výtky a výhrady ovšem“, konstatoval, „nezeslabují úhrnného soudu o jeho plné vědecké kvalifikovanosti a spisovatelské zdatnosti“.

Návazně se Fischer věnoval „otázce národní“. Konstatoval: „Mateřština dr. Messera je německá“, což však - upozornil - bylo od počátku zřejmé, připomněl komentář Jaroslava Bidla k jarnímu referátu přidruženému $\mathrm{k}$ habilitačnímu návrhu, že „,běži o připad analogický se zastoupením germanistiky na univerzitách polských“. Následně Messerův př́pad změřil poukazem k základnímu právnímu (sebe)vymezení mladého státu:

„K dodatečným principiálním námitkám, že podle zásady, do české školy patři český učitel 'nelze na naší fakultě habilitovati Nečecha, podotýkáme, že univerzitní posluchač není dítè, umí rozeznávati vědeckou a didaktickou schopnost učitelovu od jeho smýšlení politického a sociálního, a tak různost národního pưvodu a smýšlení ani neotřese jeho národním vědomím, ani mu nezabrání přijímati poučení. Zásadně vylučovati Němce z učitelství na univerzitách Karlově, Masarykově, Komenského odporuje ústavní listině republiky, jejíž státni občané jsou si pred zákonem rovni nehledic k tomu, jaké jsou rasy, jazyka nebo náboženství, a jež výslovně uvádí, že rozdíl v jazyku není státním občanům na závadu, pokud jde o prístup $k$ úradìm a $k$ hodnostem $[\ldots]^{\text {‘. }}$.

Jmenoval řadu příkladů cizojazyčných, ba německojazyčných odborníků působících na univerzitách v prostředí převážně slovanském - mj. i Spiridiona Wukadinoviće, který „,nedávno byl na krakovskou univerzitu povolán za germanistu“: „Němec, jenž se zabýval též slovanskými literaturami a byl znám svými slovanskými sympatiemi“. Pokračuje: „Také na naší univerzitě uči řada Nečechů a nebylo by správné tèti je nazeznávati př́slušníky národi̊ spřátelených a jiných, ježto to by znamenalo zasahování měř́tek ménící se politiky do věcí univerzitních." Fischer uznal, že Messer dosud česky př́liš neumí, důvěřoval však kandidátově píli v tom směru a žádal, aby „,po krátkou přechodnou dobu“ mohl Messer přednášet německy: „vždyt’ jde o německou literaturu a na Karlově univerzitě přednáši se nejen česky, nýbrž - nehledě k cvičeni lektorů - i latinsky, rusky, francouzsky, italsky. Př́mé vyloučení německého jazyka bylo požadavkem Němců a platilo pro ,c. k. univerzitu Karlo-Ferdinandovu s přednáškovou řeči českou: Univerzitě Karlově však zákon ze dne 19. února 1920 [...] vrátil všechna práva starobylého učení Karlova, jehož jest pokračovatelkou: smí tedy rozhodnout i o výjimečném využivání kteréhokoli jazyka, nebot' není již zákona, který by to zakazoval."

Od zřetelů odborných a státoprávních - otázek vnitřních univerzitních pravidel, ale také místa německé menšiny v budované republice - se Fischer přesunul k (ostatně souvisejícímu) tématu ,loajálnosti dr. Messera $k$ českému státu a jeho stanoviska k němectvi“. Nabádal k rozlišení ,projevi̊ z doby před převratem, $k d y$ [Messer, resp. toho času Meszleny] smýšlel a vyjadřoval se v duchu rakouském a nemél k našemu národu žádných vztahư" 15

15 Počátkem června Fischer - pravděpodobně s výhledem k letní schůzi profesorského sboru - prošel Křepinského námitky nanovo, viz také: ,[...] Dr. M., vychováván v Mad’arsku, vzděláván v Německu a Francii, 
a oproti tomu ,projevi̊ z doby pozdějši“، Komentář ke třem pasážím Meszlenyho spittelerovských textů de facto opakoval Krausovo vysvětlení; Meszlenyho popřevratový postoj Fischer symbolizoval měsíčníkem Das Riff, jímž se prý kandidát „ostře odlišil od smýšlení bratislavských Němců a jímž si znesnadnil, snad znemožnil vědeckou kariéru v kruzich německých“. ${ }^{16}$ Fischer časopis vyzdvihl jako projev úsilí o „kulturní sbližení všech národi̊ obývajících naši republiku, především o dorozuměni mezi Slovany a Němci“: lišil se „od propagačních časopisů vydávaných naší vládou leda tím, že [nebral] ${ }^{17}$ státní podpory. [Nebylo] tu čísla bez překladu z češtiny či slovenštiny [...]".

Messerovo „politické stanovisko“ poté ještě Fischer ilustroval zmínkou o jeho „spolupráci“"s „tiskovým odborem ministerského prezidia, Českou kanceláŕí tiskovou, redakcí Prager Presse a jinými úředními institucemi“, „chování občanské“ poukazem k „,dopisu bratislavského policejního ředitele Slavíčka“, na něhož se prý „obrátil pan profesor Vysoký o informaci [...]“: uvedl Slavíčkova slova o Messerovi jako „občanu vǐči našemu státu nejenom loajálním, ale i př́mo patriotickém [...]“. „,V předtuše, že toto sdělení bude vzato plněv úvahu“, psal v citovaném dopise Slavíček, ,dovoluji si skončit dopis podotknutím, že nepríznivé posouzení věci dr. Messera mělo by v zápětí úsudek zdejší německé i mad'arské strany, jižz je vyličená činnost dr. Messera ve prospěch našeho státu také dobře známa, vyznívající v ten smysl, že tak to dopadne s člověkem, který hlásal veřejně, že Němec může být dobrým patriotem československým."18

Stejně jako Kraus se Fischer vyslovil i k námitkám směřujícím proti kandidátově povaze. Jeho reflexe přitom nebyla zdaleka apologetická. „Referát habilitační komise netajil se tím“, konstatoval Fischer, ,že u dr. Messera je vyvinutá jistá schopnost akomodační, která svou horlivostí nepůsobi dojmem nejpřiznivějšim". Odmítl však argument jmenný: „Při dvojí změně jména dlužno ovšem uvážiti, že se Messer na Meszleny překřtil v mladých letech spolu se svým otcem, který as jednal pod nátlakem v Uhrách obvyklým, a že se nyní tohoto jména, $k$ němuž nemá pietních závazků, opět zbavil [...]“. V závěrečném shrnutí Fischer Messera definoval jako „Němce, jenž se plně hlásí k našemu státu a usiluje o syntézu nazíráni svého s kulturním prostředím slovanským".

„O něm neplatí, co tak často bývá vytýkáno Němcům: že se nezměnili, že se válečnými a poválečnými událostmi nepoučili, že nepočitají s novou skutečností slovanských státio a s nutností smírné kulturní spolupráce. Dr. M. je Němec, jenž se staví do služeb našeho státu; jenž ochotu spolupráce a nové orientace zpưsobem až manifestačním projevuje

působě ve Švýcarsku, nepřicházel ve styk s myšlenkami slovanskými, před válkou ani za války nezabýval se politikou a nadějemi českými, nezapíral jako rodilý Němec svého německého smýšlení, jehož ovšem neprojevoval šovinisticky, byl loajální příslušník monarchie a její armády a na několika místech své knihy o Spittelerovi, jež pan profesor Křepinský cituje, dává projevu svému německému vlastenectví, a to obvyklým, řekl bych konvenčně rétorským způsobem jako většina německých učenců za války; popud byl mu $\mathrm{k}$ tomu dán zvláště předmětem jeho práce, s jehož dohodovým stanoviskem se neidentifikuje [...]“ (LA PNP, f. O. Fischer, cizí rukopisy, fasc. Messer - Křepinský. Doklady k univerzitní záležitosti, Odpověd' O. Fischera na návrh, 2. 6. 1923).

16 Srov. znovu paralelní místo z Fischerova červnového textu: „Pro neúčast německého čtenářstva byl německý tento časopis odsouzen k zaniknutí, politický pak či kulturně politický ráz časopisu Das Riff byl (podle soukromých informací) jednou z příčin, proč Dr. M. nemohl počítati s možností habilitace na německé univerzitě pražské" (tamtéž).

17 Fischer z nějakého důvodu vyznačená slovesa drží v prézentu.

18 LA PNP, f. O. Fischer, cizí rukopisy, fasc. Messer - Křepinský. Doklady k univerzitní záležitosti, vyjádření O. Fischera, květen 1923. 
a tím si znesnadňuje možnost součinnosti se svými krajany Němci; jenž se hlásí k programu národni snášenlivosti; $k$ myšlenkám herderovského němectví, jež se snaži uplatňovati též svým bádáním odborným. Neběži o to, aby byl Němec poskytnutím veniae legendi za své př́telské smýšlení odměněn: otázka odmitnout-neodmítnout znamená naopak, má-li náležitě kvalifikovaný kandidát býti vytrestán za to, že se odhodlal býti Němcem jiným než většina jeho rodáků, má-li býti kárán za to, že se k našemu státu chová tak, jak si přejeme, aby se Němci chovali."19

Koncem května 1923 Novák Messerovi odpověděl na citovaný dopis, bojovně naladěn. „Milý priteli, byl jsem týden ve Vídni a dostávám teprve nyní Váš dopis. Jsem docela na Vaši straně a pokládám nové šovinistické stanovisko některých pánů pražské filozofické fakulty za úplně zvrácené. Chci Vám rozhodně pomoci, a to nejen u prof. Zubatého, na nějž se př́mo obrátím, ale pokusím se působiti i na prof. Křepinského, a to prostřednictvím našeho společného pritele. Učinil bych kroky ihned, ale Vy sám píšete, že musite podati nejprve o věci podrobné informace ústní. Jen nebude-li tento odklad Vám darmo škoditi? Musíme tedy o věci spolu promluviti. [...] Pomoci Vám tentokráte pokládám za svou povinnost a za prirozený di̊sledek všech svých dosavadních krokủ. Ostatně jsem v duchu počital s tím, že se podobné nesnáze naskytnou, a dávno jsem jejich domnělé di̊vody v duchu úplně odzbrojil. Nebyl bych mužem, kdybych soud svi̊j neřekl také otevřeně činitelìm o věci rozhodujícím." 20

V polovině června byla sice „lektoru Dr Messerovi“ při zasedání profesorského sboru schválena ,remunerace za německé kurzy“, otázka jeho habilitace však zůstala mimo (zaznamenanou) rozpravu. ${ }^{21}$ Přesto patrně v prostředí fakulty rezonovala: Kraus den po zasedání psal Novákovi: „Setkáváme se zde s mnohou nedưvěrou a zaujatostí ve snaze o získání dra Messera pro univerzitu. Nerozumím tomu, protože nechci rozuměti přiliš dobře. Prozatím se věc protáhne přes prázdniny a bojím se, abychom, propadneme-li pres v̌̌echno, nedali jistým kruhům bratislavským př́činu ke - Geronovu smíchu."22

\section{Ježek za scénou}

Dne 24. července psal pak Kraus Fischerovi: „Drahý přiteli, posilám Vám k nahlédnutí korespondenci, která vznikla tím, že mi p. Ježek poslal svou knihu s doprovodem, na nějž jsem zdvořile odpovéděl. Je to přimo kriminalisticky zajímavé nahlédnout do továrny, v níz vznikl protest Křepinského. Rozhodně se můžeme těšiti na polemiku novinářskou.

19 Tamtéž. Srov. paralelní pasáž z červnového Fischerova komentáře: „[...] pro mne však otázka odmítnout neodmítnout neznamená, jako pro pana prof. Křepinského, má-li být Němec poskytnutím veniae legendi za své přátelské smýšlení odměněn, nýbrž naopak: má-li býti plně náležitě kvalifikovaný kandidát býti za to trestán, že se odhodlal býti Němcem jiným než většina jeho rodáků, má-li býti trestán námi kárán za to, že se k našemu státu chová tak, jak si přejeme, aby se Němci chovali. / Z těchto důvodů dovoluji si navrhnouti, aby se přes protest pana prof. Křepinského od dalšího habilitačního řízení s dr. Messerem neupouštělo“ (LA PNP, f. O. Fischer, cizí rukopisy, fasc. Messer - Křepinský. Doklady k univerzitní záležitosti, vyjádření O. Fischera 2. 6. 1923).

20 LA PNP, f. O. Fischer, dopis Arne Nováka Richardu Messerovi, Brno, 29. 5. 1923.

21 AUK, f. FF UK, kart. 3, i. č. 42, Protokol o schůzi... konané 14. června 1923.

22 LA PNP, f. A. Novák, dopis Arnošta Krause Arne Novákovi, Praha, 15. 6. 1923. „Geronův smích“ je aluzí ke stejnojmenné básni z Nových písní (1888) Svatopluka Čecha, ke smíchu, jímž saský markrabě Gero spokojeně doprovází vyhlíženou zkázu svých nenáviděných protivníků. 
Co se týče mého ,slibu', nepamatuji si na něj, ale rozhodně nemohl býti učiněn, když už jsem měl materiál habilitační v rukou, nýbrž pocházi asi z doby, kdy mne obtěžoval svými plány a nevěděl, jakým spisem se habilituje. Je zde krásně a člověk si marně kazí náladu takovou korespondenci. "23

Bez kliček tu Kraus Křepinského akci spojil s polemickým napětím rýsujícím se kolem osoby Jana Ferdinanda Ježka. ${ }^{24}$ Tato provázanost se odtud stala součástí interpretace, již Messerovi podporovatelé sdíleli a ve svých dalších úvahách propracovávali. Koncem července psal Fischer Novákovi:

„Ještě jednu věc bych měl s Tebou probrat, ale je mi líto letního času, těmi nechutnostmi plýtvat dobu prázdně - týkají se naší germanistické habilitace, zpod niž se to ted' klube antagonismem toho vele- a velemilého pana Ježka. Ani nevím, stihl-li tě Messer (taky krásně bojovné jméno!) v Brně a jsi-li do detailů zasvěcen - dostals svého času můj lístek z Křvoklátu: Ale passons, je to krušné o tom psát, chystá-li se člověk jako já konečně už na dovolenou - dostal jsem laskavostí Lomovou stipendium na cestu do Tyrol a do Itálie $[\ldots]$. . ${ }^{25}$

Několik dní nato reagoval Fischer na Krausovu zásilku: „Drahý pane profesore, nejraději bych si ty dopisy Ježkovy ponechal a přiložil je ke, kauze Messer'; ježto mi je však posiláte jen k nahlédnutí, nezbývá než abych Vám je, těsně před svým odjezdem na dovolenou, vrátil. Po prázdninách mi je lask. zapůjčite znovu. Zdá se, že pan J. podrobí Messerovu publikaci nemilosrdné kritice, patrně mu p. Bello tu kritiku vytiskne, to je jejich dobré právo. K věci poznamenávám jednak, že nechutná záležitost stává se dvojnásob protivná, objevuje-li se ve scéně takovýto aktér, jednak, že máte ovšem pravdu svou poznámkou o vlastním inspirátoru té tahanice.

Myslím ovšem, že na vlastním průběhu naši akce se tím nic nemůže změnit, že se leda $v$ seděni komise o tom novém (či starém) činiteli soukromě zmíníme. Dostávám znova od Messera lístek, jehož čeština žel, ani odpưrcưm Ježkovým, nevyhoví.

Prosím jen, abyste měl, pane profesore, na paměti, tento tuším ne bezvýznamný akt: Proti habilitaci J. nejostřeji vystupoval p. prof. Janko; on to byl, jenž poukazoval na chyby v publikaci před habilitačním spisem. On s Vámi pozměnil můj návrh resp. Ježkovu habilitačnížádost a s Vámi zvážil jeho venia legendi. Co mne se tkne, skoro ted' lituji, že jsem byl benevolentni <* Messer také není vědecké lumen. To dobře vím. Ale nad pana J. vyniká velice!>, jak jste mi tolikrát řekli, snad vyčítali, nebot’ pan Ježek se stává ,obtížným ‘ docentem, jiného výrazu pron̆ nemám. To ovšem mezi námi. Svou novou knihu mi přinesl, ale nedostal jsem se posud $k$ četbě. Je dobrá?"26

Den poté psal Novák Fischerovi: „S Messerem jsme se bohužel nesetkali, ale jeho věc mně leži opravdově na srdci; pokládám ho za vědecky velice schopného a politicky spolehlivého. Sám mně svou při, v niž chci intervenovati, vyličil tak, že opozice v profesorském sboru pracuje lžiargumenty šovinistickými, což jest stejně hloupé jako nepoctivé. Že by ježatý Stormovec hrál úlohu, snad postranního intrikána, dozvídám se teprve od Tebe. Jsem dávno přesvědčen, že jeho habilitace byla faux pas jako každý podobný čin z útrpnosti ve

23 LA PNP, f. O. Fischer, dopis Arnošta Krause Otokaru Fischerovi, Kunžvart, 24. 7. 1923.

24 Viz zde pozn. 10.

25 LA PNP, f. A. Novák, dopis Otokara Fischera Arne Novákovi, 28. 7. 1923.

26 Masarykův ústav a Archiv Akademie věd ČR, v. v. i. (dále MÚ AAV), f. A. Kraus, dopis Otokara Fischera Arnoštu Krausovi, 31. 7. 1923. 
vědeckém životě. Nezbývá, než to, co Němci jmenuji ,ihn kalt zu stellen'. A to bez ohledu! Než dosti o tom!" 27

Nastal čas intervencí, příprav k rozhodné konfrontaci. Mezitím, koncem srpna, se objevil první a nadlouho jediný referát o Messerově rilkovské knize. F. V. Krejčí v Právu lidu pochyboval o možnosti její širší české rezonance: „O většině obsahu [...] nutno pohříchu ř́ci, že nenajde u něho [tj. ,českého čtenáře“] potřebné znalosti básnika, o nějž jde. Kromě několika málo literátů a odborných germanistů, stěži kdo u nás zabýval se bliže Rilkeovou poezií, dnešní naší literární mládeži zdála by se ona přirozeně přiliš romantická a mystická, a pak, kolikpak lidí z poválečné generace sleduje vůbec německou literaturu! Má proto kniha Messerova prazvláštní a jistě že velmi těžké postavení. Vykládat a analyzovat básníka před obecenstvem, jež tohoto básníka nezná! Jež ho v českém překladě nikdy ani poznati nemůže, ježto je nepreložitelný!"“ Messerovu práci nicméně Krejčí „,čtenářstvu“ doporučil jako podnětný př́íklad „,subtilní duchaplnosti“, „hlubokého vzdělání literárního“, schopnosti „,navazovat překvapující souvislosti mezi kulturními zjevy a vyvolávat daleké duchovní perspektivy“.28

V úvodu rŕíjna Arne Novák obeslal Josefa Zubatého:

\section{„Slovutný pane profesore,}

dovoluji si hned ze začátku akademického roku obtěžovati Vás žádostí v nedůtklivé a závažné věci, kde rozhodnuti profesorského sboru filozofické fakulty Karlovy univerzity záleži na Vaši dobrotivé moudrosti a autoritativní vážnosti. Jak se dojista ráčite upamatovati, bylo před prázdninami ve sboru jednáno o germanistické habilitaci dra R. Messera (Meszlenyiho), ale věc posunuta do nového šk. roku a z habilitační komise, která se pro dra Messera velmi príznivě vyslovila, přenesena na komisi širší, v níž, tuším, Vy předsedáte. Není-li o vědecké zdatnosti dra Messera, dávného osvědčeného pracovníka v liter. dějepise, pochybností, využily se námitky proti jeho kvalifikaci národní, a proto právě zvolena ona rozšírená komise. Dr. Messer, rodák z Pančeva, jest Bratislavan, Němec pưvodem, jenž se musil za uherské vlády přiznávati k mad'arské národnosti, ale hned po prevratě se nejen prohlášením, ale i skutky - vydávalt'v tom duchu revui Das Riff-prihlásil k naši republice, jal se učiti česky, a jak jsem se mnohonásobně presvědčil, chce a dovede býti horlivým státním občanem, jenž touži v novém státě vyžiti se také vědecky, $k$ čemuž habilitace v Praze, patrný to stupeň pro akademickou dráhu v Bratislavě, má býti prvním krokem. Neupírám, že dr. Messer jest jak řikáme okt’ábrista, ale vím, že jest jedním z nejčestnějšich a v svém oboru nejschopnějších. I přimlouvám se za něho u Vás co nejvřeleji: Vy, jenž se dovedete divati na dějiny národi̊ a duchovních proudů ze širokého hlediska, chápete zajisté, že takovou otázku, pravý to produkt doby prechodné, nelze řešiti ze stanoviska čirého šovinismu, a uvážite dojista di̊vody mluvicí pro dra Messera. Prosím Vás za to a děkuji Vám napřed uctivě. Nemám sám $k$ dru M. jiných vztahů než vědecký zájem a mužnou úctu. “29

27 LA PNP, f. O. Fischer, dopis Arne Nováka Otokaru Fischerovi, Proseč, 1. 8. 1923. Pojem „Stormovec“ se váže k Ježkovu zájmu o dílo Theodora Storma - spis Theodor Storm a Německo Ježek také předložil v lednu 1921 jako práci habilitační, pročež mu na základě dalšího řízení byla v červnu téhož roku habilitace výnosem ministerstva školství a osvěty potvrzena, a to pro obor „dějiny německé literatury 19. století“ (AUK, f. FF UK, kart. 29, i. č. 344, J. Ježek, Zpráva komise o habilitační žádosti p. Dra. J. Ježka, referent Josef Janko a Otokar Fischer, [listopad 1928]).

28 Šifra K., Dr. Richard Messer: Moderní pražský mystik, Právo lidu 32, 1923, č. 199, 26. 8., s. 11.

29 MÚ AAV, f. J. Zubatý, dopis Arne Nováka Josefu Zubatému, Proseč, 6. 10. 1923. 
Podobně Novák obeslal téhož dne i dalšího z dodatečně pověřených členů komise, Josefa Šustu - uvedl svou intervenci jako ,ochranné sli̊vko za Dra R. Messera, jehož habilitace na Karlově univerzitě se tak těžko a pomalu rodi“" „Jste členem rozšírené komise, která má zkoumati jeho národní integritu. Nemám nejmenši pochybnosti o tom, že nahlédnete, jak nesmyslné jest vůči němu stanovisko intransigentního šovinismu, kterým se někteři členové sboru vychloubaji: naše anexe Slovenska nás přimo zavazuje, abychom se smírili s takovými okt'ábristy, jež si poměry vynutily, jen když to jsou mužové ve svém oboru hodnotni a mravně čestní. O vědecké kvalifikaci Messerově promluvila habilitační komise velice príznivě, o karakternosti jeho jsem se presdvědčil opětovně. Že jest opravdovým republikánem, osvědčil svou propagační činností v revui Das Riff, kde pohřbil velký kus svého jmění. Ostatně, myslím, že račte býti do věci prof. Messera docela podrobně zasvěcen, a že bych Vás zbytečně meškal uváděním detailü. Toužil jsem jenom upozorniti Vás nan̆ sympaticky, jsa napřed přesvědčen, že vjeho věci zaujímáte stanovisko mému velmi blizké. Děkuji Vám napřed za všecko, co pro něj uděláte."30

V Novákově pozůstalosti se bohužel nedochovala odpověd’ ani na jeden z těchto dopisů. Dne 15. ř́jjna adresoval J. F. Ježek tehdejšímu děkanu, patrně již Františku Krejčímu, vzkaz: rozhodl se v novém semestru nepřednášet, protože mu prý, „člověku ve službách českých zasloužilému a v odboru vědeckém nikoli neznámému, soustavně odpírá to, co cizinci bez zásluh a bez významu je poskytováno týmž úr̆adem ministerským beze všeho státní úřad i dovolená" - k tomu Ježek ještě připojil doušku: „Já budu zatím publikovat dále - já se utahat nedám [...]“.31 Deset dní nato se sešel profesorský sbor filozofické fakulty. Bod č. 10 v zápisu ze schůze se týkal Messerovy věci. Fischer coby referent přečetl „zprávu většiny komise, která navrhuje, aby se pokračovalo v habilitačním řizení s Dr. Messrem". ${ }^{32}$ Nato Křepinský jako jeden z členů komise podal návrh jiný, naprosto protichůdný - „aby Dr Messer nebyl pripuštěn $k$ dalšímu habilitačnímu řizení podle § 6. habilitačního řádu“. Děkan Fr. Krejčí vybídl „pro přehlednost“ k diskusi „zvláště o jednotlivých momentech, jako védecké kvalifikaci, osobním momentu, znalosti češtiny“, a prohlásil, že ,nemůže připustiti diskusi o právu občanů Československé republiky nečeskoslovenské národnosti kjakémukoli úřadu a kjakékoli veřejné funkci, a tedy i k docentuře na Karlově univerzitě, ani diskusi o tom, zdali vyučovací reč Karlovy univerzity jest českác،. Dle zápisu se debaty zúčastnili Jos. Zubatý, Jos. Šusta, Hynek Vysoký a Jos. Janko, „,vědecká kvalifikace Dr Messera“ byla následně „uznána 23 hlasy“ (dle záhlaví zápisu bylo přítomných 29 profesorů, patrně však byl ve výčtu opominut Křepinský, uveden nebyl ani A. Kraus). „K debatě o osobním momentu a znalosti češtiny se neprihlásil nikdo“, bylo dále v zápise konstatováno. Poté se již hlasovalo o Křepinského návrhu ,jakožto širším“: „z 33 lístků 17 bylo pro návrh, 15 proti návrhu a 1 byl neplatný. Byl tedy návrh prof. Křepinského prijat. "33

30 Národní archiv, f. J. Šusta, dopis Arne Nováka Josefu Šustovi, Proseč, 6. 10. 1923.

31 AUK, f. FF UK, kart. 29, i. č. 344, J. Ježek, dopis J. F. Ježka děkanovi FF, Praha-Vinohrady, 15. 10.1923. Pochybnosti, co se týče výuky v zimním semestru, vetkl Ježek již do dopisu témuž adresátovi 9. října t. r., tam však nijak nenaznačil srovnání s ,cizincem bez zásluh“ (tamtéž).

32 AUK, f. FF UK, kart. 3, i. č. 42, Protokol o schůzi... konané 25. 10. 1923, bod 10.

33 Tamtéž. Dle zápisu se schůze zúčastnili a o Křepinského návrhu hlasovali: M. Hýsek, G. Friedrich, O. Kádner, Fr. Lexa, O. Jiráni, R. Růžička, M. Novotný, A. Wenig, Birnbaum, V. Mathesius, Z. Smetánka, J. Baudiš, J. Šusta, J. Janko, H. Vysoký, J. Zubatý, M. Murko, O. Fischer, F. X. Šalda, J. Jakubec, J. V. Šimák, K. Chytil, J. Pekař, B. Foustka, O. Hujer, J. Chlumský, Fr. Groh a Fr. Krejčí. 
Zápis je lakonický, avšak atmosféra ve chvíli projednávání Messerovy věci patrně poklidná nebyla. Soubor rukopisů, jež se dochovaly ve společné messerovské složce ve Fischerově pozůstalosti, uzavírá text prohlášení, jež Fischer sepsal den po schůzi:

„Polemizuje s mými referáty o vědecké kvalifikaci dr Messera, užil pan prof Křepinský $v$ seděni sboru dne 25. ř́jna t. r. mj. výrazu, že mé jednáni bylo takové, jaké nebývá zvykem ve slušné společnosti. Ježto za tento obrat nebyl p. děkanem volán k pořádku; ježto mi nestači sumární omluva pronesená p. prof. Křepinským po jeho referátu; ježto, když nebyl připuštěn $k$ slovu p. prof Kraus, ani já jsem se již o ně nehlásil; a ježto výraz mnou citovaný nebyl jedinou urážkou habilit. komise resp. jejich členů: žádám zdvořile, bud' aby byla dosazena komise, jež by přezkoumáním aktĩ zjistila, byl-li p. prof. Křepinský oprávněn uživati výrazi hanlivých, anebo aby plénum sboru se vyslovilo o tom, shledává-li způsob a tón referování p. prof. Křepinského slučitelným s dưstojností profesorského sboru naši fakulty." 34

Několik málo dnů po této schůzi Ot. Fischer psal Novákovi: „Snad již vís, že jsme to ve sboru čestně prohráli ve věci Messerově; se svým, vitězným 'odpuircem v̌̌ak měnit bych nechtěl, ani co do stanoviska, ani do védomí vykonané povinnosti, a už dokonce ne do pojmu o noblese polemiky." ${ }^{55}$ Novákovi bylo Messera „líto“: „sám jsem se za něho přimlouval u Zubatého a Šusty, ano i na Křepinského dal jsem působiti, arcit’s malým prospěchem. Zvitézila Zlámaná Lhota nad Evropou. Nevím, zda se nemýlim, prisuzuji-li protimesserovské tažení [...] jeho aranžmá Ježkovi. Měli jste ho za neškodného hlupáka, ale žádný hlupák neni neškodný, zvláště octne-li se v profesorském sboru. “36

\section{Ježek na scéně neboli ježatá ohlédnutí}

Krach Messerova habilitačního ř́izení však Ježkovi bezstarostný rozvoj akademické kariéry nepřinesl, naopak. Ještě v prosinci vyšel v Prager Presse text polemicky zahrocený proti jeho knize Bratři a demokraté. Ježek se vůči němu ohradil v Národních listech. ${ }^{37}$ Josefu Zubatému psal ještě posledního dne toho roku - v souvislosti se svou snahou o rozširření docentury „,na celý obor německé literatury“ (oficiálně podá žádost 11. 1. 1924). V rozkladu o misi české germanistiky učinil z Messerovy knihy o Rilkovi (aniž by Messera jmenoval) príklad selhání:

„Tu si zajisté dovedete představit, jak se mne musel dotknout listek Novákův, toho Nováka, který hlavními myšlenkami mého spisu o božím hodě Vánočním naplnil celý skvostný úvodník Lidových novin. ${ }^{38}$ Věc je mi tím podezřelejši, že naši germanisté se halí v naprosté

34 LA PNP, f. O. Fischer, cizí rukopisy, fasc. Messer - Křepinský. Doklady k univerzitní záležitosti (1923), polemika Otokara Fischera.

35 LA PNP, f. A. Novák, dopis Otokara Fischera Arne Novákovi, 29. 10. 1923.

36 LA PNP, f. O. Fischer, dopis Arne Nováka Otokaru Fischerovi, Brno, 1. 11. 1923. V druhé půli téhož měsíce psal Lubor Niederle Aloisi Musilovi do Londýna: „Ve sboru máme antisemitské hnutí vyvolané pokusem habilitace nějakého Němce dra. Mesmera [sic] (z Prager Presse). Byla z toho bouře minule, ale já jsem odešel před ní“ (Muzeum Vyškovska, f. A. Musil, 20. 11. 1923; za upozornění na tuto pasáž děkuji Pavlu Žd'árskému).

37 Šifra e. [Paul EISNER], Brüder und Demokraten, Prager Presse 3, 1923, č. 339, 11. 12., s. 4; Jan Ferdinand JEŽEK, Jak Prager Presse polemizuje, Národní listy 63, 1923, č. 340, 12. 12., Př́iloha, s. [1].

38 Míněn patrně text Narození boži (Lidové noviny 31, 1923, č. 645, 25. 12., s. [1]). 
mlčení. [...] Proč se tak děje? Jsem já snad proti Židům, když myslím, že naše německá literární historie nikterak nevyžaduje původ z tohoto národu, ba že my povahově i kulturně máme k Němcům mnohem bliže než k těmto prostřednikuim? Já proti slušným Židům nejsem, mým největším dobrodincem byl Žid Leo Kohn ve Znojmě - to přec mluví dost žretelně. Nebo jsem proti Němcům, že znám jejich dobré i špatné stránky, že k oněm ukazuji a z těchto varuji, a že se domáhám toho, abychom v této věci nesetrvávali pouze při půdorysu (gramatice) a při střě̌e (literatuře), nýbrž vybudovali vědu o německém národě vỉbec.

Dovolte, slovutný pane, letos vyšla 3 germanistická díla u nás, Bratři a demokraté, Heine a Rilke, a hled'te, jak se v nich př́mo osudově obrážeji životní zkušenosti, charaktery, snahy a cíle jak autorů, tak národů. Můj spis usiluje o naše zesílení, nevidí spásu ani v nacionalismu, ani v socialismu, nýbrž v božnosti, vyrovnávajicí všecky př́krosti stavovských rozdili̊ a národnostnich protiv přes rozdíly ve vyznání - Fischerưv spis potvrzuje bezděčně a contrario tuto mou vnitřni tendenci heinovským a svým vlastním ahasverstvím (sleduju Fischera už dlouho, vědce i básníka, a vyznávám, že je mi jeho trýzně upř́mně líto). Ale toto ahasverství není u nás jen problémem židovským, nýbrž také naším německým problémem, a problémem všech našich menšin státnich, jak ukázal, sám na sobě zažil Rilke. Ale náš nový spis o Rilkovi se toho ani nedotýká, ač vybíhá v nabídku prostředníka mezi Germány a Slovany, podobně jako Tell-Probleme z r. 1911 se nabizeji k prostředkujici roli mezi Germány a Romány; ba je tak dalek podstaty zajímavé bytosti Rilkovy, že ani nepostihuje elipsovitých center a linií jeho vývoje od husitství k buddhismu, a bůh ví kam ještě, já myslím, že už nikam.

Pomalu začinám chápat, co ti páni proti mně mají; já jim asi odbočuji př́liš od německé tradice literární, svádím do kolejí ryze českých, pod hlediska našeho vkusu a našich potřeb. Tomu bych se však musel velice divit, to měla přece naše něm. literární historie a kritika dělat už před 30 lety; konečně myslím, že také německé germanistice (v ř̌iši) jinak ani nemůžeme prospět (prostřednictvím našich Němců) [...] P. prof. Kraus tu začal, začal, ale nedošel pro toho sv. Jana Nepomuckého tak daleko, jak mél. Nuže, on může řici, tak dělejte ted' $V y$ !

Ale tu zas mu musím ríci já: rád, milerád, ale neházejte nám klacky na hlavu [...]."39

Krausovu pozici Ježek opakovaně chápal jako zradu na určité úmluvě. „Co se změnilo?", uvažoval v dalším dopise J. Zubatému, „P. prof. Kraus obrátil, když začala pracovat klika a když se k té klice priklonili činitelé vládní. Tak jsem informován já. Od té kliky je to pochopitelné, od ostatnich činitelu nikoli, to nebylo ani čestné, ani prospěšné [...]"“. ${ }^{40}$ Zatímco Messer dál na filozofické fakultě vedl coby lektor kurzy němčiny, Ježek se postupně propadal do komplexního konfliktu: profesorský sbor ,jednohlasně zamítl“ jeho žádost o rozšíření habilitace, ${ }^{41}$ Arne Novák jeho habilitační knihu o „bratřích a demokratech“ (vydanou počátkem roku 1924 pod novým titulem My a Němci. Německá otázka ve světle

39 MÚ AAV, f. J. Zubatý, dopis Jana Ferdinanda Ježka Josefu Zubatému, Praha-Vinohrady, 31. 12. 1923.

40 MÚ AAV, f. J. Zubatý, dopis Jana Ferdinanda Ježka Josefu Zubatému, Praha-Vinohrady, 1. 1. 1924.

41 Podkladem k odmítnutí byl odmítavý posudek Ježkovy knihy, který vypracoval především Kraus, nicméně ve spolupráci s Jankem a Fischerem; Ježek v dalších měsících usiloval o zveřejnění tohoto posudku, Kraus jej nakonec - avšak teprve v březnu 1925 - publikoval v Časopise pro moderní filologii (11, 1924/1925, č. 2, s. 162-171; srov. též Václav Ретrвoк (ed.), Arnošt Vilém Kraus /1859-1943/ a počátky české germanobohemistiky, Praha 2015, s. 330-345). 
německé literatury) př́kře posoudil v Českém časopise historickém. ${ }^{42}$ Proti Novákovu textu vystoupil Ježek v Českém slově, počínaje slovy: „Ve vědeckých pracích neřídí se vždy autoři motivy vědeckými. Arne Novák proslul tím již často. Někdy sahá až k nadávkám a osočování $[\ldots]$ “. “43 Své prekérní postavení Ježek artikuloval v následných měsících ve směsi veřejné polemiky 44 a korespondence s některými členy profesorského sboru. $V$ dopisech vznikajících v tomto napjatém rozpoložení se nezřídka ohližžl zpět. V tomto rámci se opakovaně, ačkoli nejmenovaně vynořoval i R. Messer.

V dubnu 1925 psal Ježek Jankovi: „, [...] rány z konfliktu metod a presvědčeni mé nebolí, ale ran z 1/2 tuctu polopravd a tuctu lži nesnesu, a tedy také nestrpím. Proto Vás žádám, abyste nebránil, nýbrž podporoval moji snahu o mezifakultní (fil. fak.), mezikonfesijní a mezinárodni komisi a vyřešení pré. Je to proto nutné, že boj proti mně byl zahájen podloudně p. Pavl. Eisnerem z Prager Presse ve jménu kadence protižidovské. A když to se nezdařilo, Arne Novákem ve jménu kadence protikatolické, a průvodni úředni recenzi ve jménu kadence protiněmecké.“"45

O několik měsíců později adresoval děkanovi (bud’ ještě Emilu Smetánkovi nebo Janu Jakubcovi) dopis bojovně vyhrocený vůči „pražské germánské komisi a odboru“, hrozil „žalobou pro lži [...] v úřední recenzi“" a citoval zde ze svého staršího hovoru s Jos. Zubatým jeho repliku: „Vidite, to je to, co se mi na Novákovi nelíbí, mně psal o tom pánovi $v$ posledni době (prosinec 1923) dvakráte, a já jsem mu ani neodpověděl"“, dodávaje:

„Psal-li ten švec prof. Zubatému z naprosto odlehlého odboru do pražského sboru, jak by byl nepsal do odboru germánského? A tu je otázka: jakým právem tak činil? Může vědec - literární historik se švýcarským osvoboditelem vážně srovnávat fantazii o vládě peněz (Tell-Probleme)? Může takový literární historik se jménem a spisem o Spitellerovipacifistovi rozhodném srovnat vážně v témž spise nadšeni pro německo-rakouský nástup vojenský? A mohl člověk, neznajicí r. 1923 vůbec česky, napsat český spis o pražském básníkovi německém česky, s presnou znalostí české literatury předmètu, a přimo s virtuózním českým slohem $v$ těch částech - selhávajicím ovšem v těch základnich věcech, kterých on přirozenè znáti nemohl a kterých, zcela nepřirozené, neznal jeho informátor a pomocník? To v̌se je, prosím, s nejvétši chválou [...] v úrednich aktech fakulty.

Srovnejte s tím laskavě, jak bylo měreno mně za těch 7 let přes všechny sliby-dovedete pochopit, že zahajuji boj s tou klikou as těmi bačkorami, které jí přisluhují [...]. ${ }^{46}$

Téhož dne sepsal Ježek pro své posluchače text, jímž jim chtěl vysvětlit svůj spor, svou situaci; mj. tvrdil, že mu nebylo obtižno vypořádat se s posudkem Novákovým v Českém časopise historickém, a to také proto, že „od nejčelnějšího reprezentanta naši české obce vědecké zvěděl, jak překvapujicí mérou se p. Arne Novák angažoval pro jistou přicestovalou osobnost, které jsem se dle všeho zdál státi v cestě [...]“..47

42 Arne NovÁk, recenze in: Český časopis historický (dále ČČH) 30, 1924, 16. 4., s. 133-136.

43 J. F. JEŽEK, Véda a Novákova politika, České slovo 16, 1924, č. 131, 5. 6., s. 1-2; týden předtím (č. 127, 31. 5. , s. 1-2) tu vyšel Ježkův fejeton Autonomie védy a prof. dr. A. Kraus. Glossy k odbornému referátu. A. Kraus na něj, vyzván redakcí, reagoval odpovědí začínající O autonomii vědy na univerzitách projevil nedávno obavu..., Národní listy 64, 1924, č. 154, 4. 6., s. 4.

44 Viz zejména brožuru J. F. JЕŽEK, Můj spor s prof. Dr. Arn. Krausem \& spol. Plaidoyer „Bratři a demokratů“, knihy sebevédomí a odpovédnosti (Praha, vl. n. 1925).

45 AUK, f. FF UK, kart. 29, i. č. 344, J. Ježek, dopis Jana F. Ježka Josefu Jankovi, Praha, 6. 4. 1925.

46 AUK, f. FF UK, kart. 29, i. č. 344, J. Ježek, dopis Jana F. Ježka děkanovi FF UK, Praha, 15. 10. 1925.

47 Koncept úvodu k přednáškovému kurzu, 15. 10. 1925, rkp., tamtéž. 
Role univerzitního vyučujícího se Ježek nakonec pro zimní semestr 1925/1926 protestně zřekl, usiluje poté - bezúspěšně - jak o rehabilitaci, tak o nové či obnovné habilitační řízení. ${ }^{48}$ Messer zůstával v jeho pojetí situace protežovaným konkurentem, jehož Ježek jako by trestal tím, že jej v bilancujících stížnostech nejmenoval - tak jako v dopise Jankovi: „,Musíte pochopit revoltu moji pro $99 \%$ židovských lži Nepřesvědčuje-li Vás ani to, pak srovnejte laskavě těchto $99 \%$ lži na zabití moje se $100 \%$ lžichválou ve prospěch pobratima [...]."49 Koncem roku 1928 komise ve složení Janko, Kraus, Fischer opět zamítla Ježkovu žádost o obnovu, resp. rozšíření jeho docentského venia legendi. Ten se 20.12. odvolal, a když neuspěl, adresoval 18. 2.1929 děkanovi (toho času jím byl Břetislav Foustka) zprávu, kde mj. konstatoval, že „si věc [vyř́íí] cestou veřejnou, která sice nepřináši pochopení otázek ryze vědeckých, ale disponuje už smyslem pro křivdu a protekcionářstvi". Širší komise čítající také Jana Jakubce a Josefa Šustu, za předsednictví Foustkova, se poté 11. 6. 1929 usnesla na (další) zamítavé odpovědi. Neúspěšný byl i další pokus v roce $1931 .{ }^{50}$ Ježek se zkrátka mezi vyučující na filozofické fakultě už nevrátil.

Pokud jde o Messera, znovu již o habilitaci nepožádal; zůstal nicméně lektorem a po polovině čtyřicátých let z této úsporné role načas dokonce i vystoupil, když se v personální i kulturněpolitické krizi, která pražské univerzitní germanistické pracoviště zasáhla, na zdejší výuce podílel - především po boku Hugo Siebenscheina - také vedením odborně, literárněhistoricky vyhraněných kurzů. Pouhé konstatování, že krach jeho habilitačního pokusu v průběhu roku 1923 způsobil - snad ze sympatie k Ježkovi - Max Křepinský, by však bylo velkým zjednodušením; zápletku totiž lze číst i jinak: stojí v ní Messer jako obět' nešt'astné konstelace, již ovšem svými předchozími a souběžnými rozhodnutími a gesty utvářeli i jeho př́znivci.

\section{Príloha}

Vyjádření prof. Arnošta Krause (Messer - Křepinský. Doklady k univerzitní záležitosti 1923, LA PNP, f. O. Fischer) $)^{51}$

Důvody, o které p. prof. dr Křepinský opírá svůj návrh na revotování usnesení prof. sboru, jsou:

48 AUK, f. FF UK, kart. 29, i. č. 344, J. Ježek, Zpráva komise o habilitační žádosti p. Dra. J. Ježka, Josef Janko (referent) a Otokar Fischer, [listopad 1928].

49 AUK, f. FF UK, kart. 29, i. č. 344, J. Ježek, dopis J. F. Ježka patrně Josefu Jankovi, Praha, 17. 11. 1926.

50 K tomu srov. Ježkův výklad v dopise adresovaném počátkem roku 1932 Arne Novákovi (LA PNP, f. A. Novák, dopis datován Praha-Vinohrady, 31. 1. 1932, a následný rozhořčený, vyčítavý list patrně reagující na rezervovaný Novákův postoj k Ježkovým aktuálním plánům (včetně habilitace brněnské); nanovo (a opět nejmenován) se tu znovu mihl i Messer: ,Jinak račte povážit, co kamení mi zde v Čechách v posledních 13 letech bylo naházeno pod nohy kvůli ambicím jistého pána, který na místo učitele na univerzitě československého jazyka nemá jistě práva ani nejmenšího. Leží-li Vám osud tohoto pána na srdci, Bůh s Vámi i s ním - jemu se přitom nedaří zle, a on je tím také spokojen [...]“ (tamtéž, Praha, 11. 2. 1932).

51 Při přepisu textu byla předloha upravena pouze tehdy, šlo-li o zjevné překlepy apod., nebo se zřetelem k dnešní pravopisné normě; $v$ jednoznačných případech byla opravena interpunkce, sousloví nahrazena patřičnými spřežkami, u slov přejatých a kořenných, předponových a předložkových s/e/- a z/e/- byla volena podoba, již lze považovat na škále knižní - progresivní za spíše neutrální. 
1. Dr Messer je Němec a Němec nemůže býti učitelem na české univerzitě;

2. Dr Messer neumí česky a není př́pustno, aby na české univerzitě přednášel jiným jazykem než československým;

3. Dr Messer je smýšlení protistátního;

4. Dr Messer svou povahou nehodí se na učitele univerzitního.

1.

Mateřský jazyk dra Messera je německý, jak v referátu komise bylo uvedeno, a lze soudit, že obvyklé v bývalém Uhersku pomad’arštění nešlo hloub než ke změně jména, nyní odčiněné. Mad'arsky, pokud víme, nikdy nepsal, nýbrž jen německy a francouzsky, ${ }^{52}$ němectví jeho lze tedy pokládati za nepochybné. Znemožňuje tato vlastnost učitelství na naší univerzitě?

Zásadně vylučovati Němce z učitelství na univerzitě Karlově, Masarykově, Komenského odporuje ústavní listině československé republiky, jejíž § 128 praví, že státní občané republiky jsou si před zákonem rovni... nehledíc $\mathrm{k}$ tomu, jaké jsou rasy, jazyka nebo náboženství, že rozdíl v jazyku není státnímu občanu na závadu, pokud jde o př́ístup $\mathrm{k}$ úřadům a hodnostem...

Zásadu p. prof. Křepinského „Do české školy patř́ český učitel“ bylo by tedy lze prováděti jen mimozákonně, kdyby vůbec bylo možné stanoviti zásadu, platnou pro učitele všech kategorií. Univerzitní posluchač není dítě, umí rozeznávat vědeckou a didaktickou schopnost učitelovu a jeho smýšlení politické a sociální, a tak ani různost národního původu a smýšlení ani neotřese jeho národním vědomím, ani mu nezabrání přijímati poučení, jak dokazují prececetní bývalí žáci středních škol německých a studenti, poslouchající na německých univerzitách v cizině nebo v Praze.

Obava, že by německým členem vnikl cizí živel do sborů profesorských, je přežitkem z dob, než jsme byli národem státním, který nemá, co by tajil; a že by takový profesor - zjev jistě výjimečný - mohl strhnouti sbor, když jejich smýšlení se rozchází, je právě tak nemyslitelno, jako že by sbor mohl reprezentovat vǔči cizině, kdyby ho sbor k tomu výslovně, volbou nebo vysláním, neoprávnil. - Nevadilo staré univerzitě Karlo-Ferdinandově, že na ní působil matematik Francouz Durège, romanista Cornu, polským univerzitám v Krakově a Lvově, že germanisty byli Němci Creizenach a R. M. Werner; slavisté na německých univerzitách bývali dříve Slované. Také na naší univerzitě učí Nečeši a rozeznávati s p. prof. Křepinským př́slušníky národů sprátelených a jiných nemáme právo, nehledě $\mathrm{k}$ tomu, že spolky politické, byt' sebevřelejší, nejsou věčné; kdo by byl r. 1914 tušil, že Bulharsko se postaví po bok Německa? Kdo může přísahat $\mathrm{v}$ trvání prátelství SHS a tím i našeho státu k Itálii? V stálé trvání čtyřdohody? Atd. Hlavním zřetelem naším jest a zůstane blaho posluchačů našich a jest zcela myslitelno, že bychom za naléhavé potřeby, kdyby nebylo domácí vhodné síly, povolali, jako činily jiné státy, učence cizího, poprrípadě i Němce, byt' bychom mu přechodně musili činiti jistě jazykové koncese.

52 V tomto se však Kraus mýlil, Messer před válkou mad’arsky publikoval, svá budapešt’ská filologická studia zakončil prací Gerstenberg költészete. Irodalomtörténeti tanulmány (Budapest, Deutsch Zsigmond és Társa Könyvkereskedése 1908; podepsáno Rikárd MESZLÉNY), a nejpozději ještě v roce 1918 otiskl v budapešt'ském listě Világ stat' o Hauptmannovi (Richárd Meszlény, Hauptmann mesternovellája: Der Ketzer von Soana, Világ 9, 1918, č. 232, 4. 10., s. 5-7). 
Že dr. Messer dosud neumí dobře česky, nepopřeli členové komise, ale vyslovili svoje přesvědčení, že se řeči brzo a dobře naučí. Byli k tomu oprávnění, poněvadž, znajíce dra Messera jako svého posluchače, měli př́íležitost pozorovati, jak rychle překonával obtíže a naučil se mluviti - podle zvláštní své metody - hbitě, a nepochybuji, že za dobu poměrně krátkou bude mluviti i korektně. Odvolává-li se p. prof. Křepinský na zákon, přikazující úředníkům, aby se naučili státnímu jazyku, je to př́lišná koncese, univerzitní profesor musí vyhovět větším požadavkům, a není pochybnosti, že p. dr Messer jim vyhoví.

Jde jen o to, nemáme-li mu poskytnout lhůtu a dovoliti mu, aby po krátkou přechodnou dobu přednášel německy, vždyt' jde o německou literaturu a přednáší se na Karlově univerzitě nejen česky, nýbrž - nehledě k cvičením lektorů - i latinsky, rusky, francouzsky, italsky. Přísné vyloučení německého jazyka bylo požadavkem Němců a platilo pro „,c. k. univerzitu Karlo-Ferdinandovu s přednáškovou řečí českou“; Karlově univerzitě však vrátil zákon ze dne 19. února 1920 (Sb. z. č 135) všechna práva starobylého vysokého učení Karlova, jehož, podle $\S 1$ zákona, jest pokračovatelkou, smí tedy rozhodovati i o výjimečném uživání kteréhokoli jazyka, nebot' není již zákona, který by to zakazoval.

\section{3.}

Zkoumajíce, je-li dr Messer smýšlení protistátního, musíme přesně rozeznávati projevy z doby před převratem, kdy neměl k státu našemu ještě žádných povinností, a projevy pozdějšími. Politické výroky v starších spisech Messerových týkají se jen poměru německého Švýcarska k Německu a jsou lhostejné. Ve spise, tištěném a vydaném za světové války, knize o Spittelerovi, nalezl p. prof. Křepinský tři zajímavá místa, jež se řadí chronologicky takto:

1. R. 1915 tiskne M. spis, vyvinující teorii, že epos žádá pohybu mas pod oligarchickými vůdci, a vidí takový pohyb, obdobný tažení Achaiů nebo Nibelungů, ve velké mobilizaci německé. Strženy jsou všechny hradby, praví, i národní, věřil tedy naivně ve svornost všech národností středoevropských s Němci a Mad'ary. Aby rekrut rakousko-uherský si uvědomil při tom brutální a bezohledné vedení války Němci, je těžko předpokládati; odkud by o tom věděl? A zjev národa zdvihajícího se v masách nikdy nebývalých, v nikdy neslýchané spořádanosti a pohotovosti, mohl imponovati i tomu, kdo cítil bolestně, že to hnutí hrozí nás rozdrtit, kdo poznal, že lid je otráven nepravdivými zprávami o otrávených studnách, pumách, zvědech, a přece mohl se závistí a podivením pozorovati, jak se celý velký národ řítí v tu válku. Oč více mohl dr Messer z kasárenského dvora viděti pouze velkolepost a dát jí výraz nadějeplný!

2. Kniha nebyla ještě dotištěna, když aféra Spitellerova rozčílila německé obecenstvo. Bylo nutno vyčkat, až bouře ustane, a po dvou letech, v dotištěné již knize, připojil řadu listů (s novou paginací), aby rozšířil úvahu o politickém rázu eposu a, vychválil Spittelera jako sociálního a politického proroka, hleděl ho omluvit před německými čtenáři poukazem na vlivy, pod kterými psal mladý básník, tj. na protiněmeckou tendenci švýcarských novin. Otiskuje ukázky bez poznámek, vyjma tři případy, z nichž první je nejasný, v druhém, když nazýván Bismarck břídilským žákem Napoleonovým, poznamenává, že tím není míněn snad Napoleon I, nýbrž Napoleon III, což je ovšem drastické; podle Bismarcka těchto představ je pak kreslen Leviathan v Prometheovi. 
V třetím případě konstatuje, že uznávali „,aspoň“, že Prusko bylo r. 1870 nespravedlivě napadeno, to byla tak obecná víra, že nás nijak nezaráží, když se dr M. nezmiňuje o emžské depeši. Zde prozrazuje ostatně, jak byl zklamán z nadšení roku 1914/15 (der Krieg... die geistige Zerrüttung die seelische Verödung unserer Gegenwart...)

3. V únoru r. 1918 je kniha konečně dotištěna a dr Messer píše předmluvu, která se začíná historií knihy a dotýká se i aféry Spittelerovy. - „In den Tagen jener gerechtfertigten oder doch begreiflichen Erregung sahen sich Verleger und Verfasser veranlasst, die Veröffentlichung hinein zuhalten, atd.“A odmítá zaměstnávat se sebeméně onou aférou.

Považme, oč jde. Spitteler, slavný německý básník, prohlásil se r. 1915 pro trojdohodu a vzbudil tím bouři odporu a zuřivosti v Německu. Rozumí se, že bylo zájmem spisovatelovým, aby položil co nejvyšší hráz mezi sebe a Spittelera; nejvítanější bylo by bývalo, kdyby se byl přidal k rozhořčení výrazy co nejostřejšími a prohlásil, že mluví o básníkovi, ne o politikovi. Ve skutečnosti Dr Messer nazývá ono rozčilení gerechtfertigt, čili volí nejslabší výraz, který mu jazyk poskytoval. Rozčilení nebylo gerecht spravedlivé, nebylo natürlich, selbstverständlich, tiefbegründet, elementar a jak by se ještě mohlo zváti, bylo jen gerechtfertigt, odůvodněno, ospravedlněno, jak lze říci o každém upřímném rozčilení; bylo omluvitelno, lze je lidem a době odpustit... ale s tímto matným označením se dr Messer nespokojuje, on připojuje oder doch begreiflichen, nebylo tedy ani ospravedlněno, bylo neoprávněné, nespravedlivé, a ovšem pochopitelné či nesoudné, poštvané masy...

„Soudíme, že tentokrát byl upřímný“ - praví o tom velmi správně p. prof dr Křepinský; ano byl tak upřímný, že se to rovná mladistvé nerozvážnosti, když byl přece důstojník, hýčkaný a za frontou dobře schovaný, a pokyn bedlivého čtenáře stačil, aby o ty výhody přišel. Tato upř́mnost nám dává nahlédnout v jeho nitro a ukazuje, že nadšení z r. 1914, které bylo „gerechtfertigt oder doch begreiflich“, vyprchalo dokonale, jeho nitro bylo prázdné, a když nadešla doba obecných převratů, mohl se rozhodnouti podle rozumu.

Jak přijal nejprve nové poměry v Bratislavě, nevychází ze spisů; nevíme, proč opustil r. 1920 státní službu a založil svou existenci na měsíčníku Das Riff. Nebyl v tomto postavení ničím vázán, mohl psáti zcela volně podle nejvlastnějšího přesvědčení a podle vkusu svých odběratelů. Jakého smýšlení jsou v Bratislavě Němci, pozná snadno, kdo jen několik dní tam mešká a čte tamní noviny. Jak se přizpůsobil p. dr Messer tomu vkusu a smýšlení?

Tak, že jeho časopis se liší od propagačních časopisů, naší vládou vydávaných jen jedinou vlastností: nebéře podpory státní. Jinak hledí spojovat literární svět bratislavský s pražským a není čísla bez překladu z češtiny, jsou tu zastoupeni J. Čapek, Dyk, Neumann, Sova, R. Svobodová, Theer a slovenské lidové písně. To uznává také p. prof. Křepinský, který nalezl ve všech číslech jedinou př́íčinu k výtce. V referátě o Doležalově knize o Masarykovi zní úvod „Zum amtlich gefeierten Geburtstag Masaryks..." Úvod podivný, snad referent míní pouze, že kniha bude dobrá pro učitele, kteří musí řečnit o svátku prezidentově, snad lituje, že i muž jako Masaryk se stává předmětem komandovaných oslav, jisto je, že by redaktor, který by výraz potlačil jako neloajální, uvalil na sebe výtku byzantinství.

Vyjde-li z těchto fakt, že na námitku p. prof. Křepinského lze odpovědět: Naopak!, plně to potvrzuje dopis p. policejního ředitele bratislavského, na kterého, jako nejkompetentnějšího svědka, se obrátil p. prof. Vysoký. Čteme v něm: „Neváhám si, velectěný pane 
profesore, s Vámi sděliti, že profesora Messera delši dobu již znám a mohu jej vskutku označit za občana vůči našemu státu nejen loajálního, ale i př́mo patriotického."

\section{4.}

Vadu mravní vidí p. prof. Křepinský v tom, že dr Messer tak snadno se vzdává jména v literatuře již známého, ale povážíme-li, že na Meszleny se překřtil jeho otec patrně pod nátlakem v Uhersku obvyklým, chápeme, že se jména co nejdříve hledí zbýti, i s obětmi, když je to možná. Pietních povinností k němu nemá.

Závažnější je zpráva, že žádosti dra Messera, aby byl převzat jako důstojník do čs. vojska, nebylo vyhověno. Ale vůči svědectví prezidenta policie, kterému by každý poklesek vůči našemu státu musil býti úředně znám, nemůže to odmítnutí působiti na naše rozhodnutí, nebot' jednak mohly úřady vojenské souditi podle některého z důvodů, které zde byly vyvráceny, za druhé jsou požadavky na důstojníka jiného rázu, zvláště na důstojníka tak důležité speciální zbraně, jako je dělostřelectvo, důstojníka již staršího, kterému by snadno mohl být přidělen odpovědný úkol.

Resumuji: $\mathrm{z}$ důvodů uvedených ani jeden neobstojí a není př́íciny, aby se upustilo od započatého aktu habilitačního, navrhuji tudíž, aby dr Messer byl k dalším krokům habilitačním připuštěn. Př́íčin věcných proti němu není a politické úvahy, mají-li již míti místo, mluví pro něho. Aspoň p. dr Slavíček končí svi̊j dopis takto:

„V předtuše, že toto sděleni moje bude vzato veleváženým panem profesorem plně v úvahu, dovoluji se skončiti dopis svịj s tím podotknutím, že nepřiznivé posouzení věci dra Messera mělo by vzápětí úsudek zdejši německé i mad'arské strany, již je vyličená činnost dra Messera ve prospěch našeho státu také dobře známa, vyznívajicí v ten smysl, že tak dopadne to s člověkem, který hlásal veřejně, že Němec může býti dobrým patriotem československým."

A. Kraus

\section{Grantová podpora}

Text vznikl v rámci projektu Richard Messer: cesta Evropou, mezi filologii a dějinami uměni, podpořeného Grantovou agenturou České republiky (reg. č. 18-01438S). 


\section{Richard Messer, ein „Zugereister“. Zu einem Habilitationskonflikt}

\section{ZUSAMMENFASSUNG}

Im Jahre 1923 versuchte der Bratislaver (Pressburger) Germanist Richard (Meszleny-)Messer anhand einer tschechischsprachigen Abhandlung über R. M. Rilke und eines Vortrags zum Thema „Die epische Mariologie der deutschen Dichtkunst vom Mittelalter bis zur Gegenwart“, sich an der philosophischen Fakultät der (tschechischen) Karlsuniversität zu habilitieren. Trotz mehrseitiger Unterstützung von Kollegen (insbesondere von A. Novák, A. Kraus und O. Fischer) wurde das Verfahren nach mehreren Monaten abgebrochen. Die Unterbrechung des Habilitationsverfahrens hatte der Romanist Max Křepinský initiiert, der selbst Messers sichtbarster Opponent war. Allerdings deuten zugängliche Dokumente auf einen breiteren Hintergrund seiner Aktion, insbesondere auf einen Zusammenhang mit Karriere-Interessen und Schwierigkeiten des Germanisten Ferdinand Jan Ježek.

Michal Topor

Deutsche Übersetzung Wolf. B. Oerter

Institut pro studium literatury, o. p. s., Praha

michal.topor@ipsl.cz 